\title{
EFEKTIVITAS STRATEGI PETA KONSEP TERHADAP KETERAMPILAN BERPIKIR KRITIS SISWA MADRASAH ALIYAH PADA MATERI KEANEKARAGAMAN HAYATI
}

\author{
Syarif Rizalia
}

Fakultas Tarbiyah dan Ilmu Keguruan, IAIN Kendari

Jl. Sultan Qaimuddin No. 17 Baruga, Kendari, Indonesia 93116

e-mail:syarifrizalia@iainkendari.ac.id

\begin{abstract}
Abstrak
Penelitian quasi experiment ini bertujuan untuk mengetahui efektivitas penerapan strategi peta konsep terhadap keterampilan berpikir kritis siswa di kelas X MAN 1 Kendari pada materi keanekaragaman hayati. Melalui non randomized pretest-posttest control group design, instrumen yang digunakan dalam penelitian ini adalah lembar inventori keterampilan berpikir kritis, tes untuk keterampilan berpikir kritis dan analisis peta konsep. Kelas kontrol adalah kelas yang menggunakan strategi konvensional, sedangkan kelas eksperimen adalah kelas yang menggunakan strategi peta konsep. Kebermaknaan hasil penelitian ditunjukkan oleh skor $\mathrm{N}$-gain dari peningkatan rerata skor pretest dan posttest siswa. Pada tes keterampilan berpikir kritis, kelas kontrol mengalami peningkatan sebesar 0,28, sedangkan kelas eksperimen mengalami peningkatan sebesar 0,38 dengan signifikansi sebesar 0,029. Hal ini menunjukkan bahwa penerapan strategi peta konsep efektif namun tidak signifikan dalam meningkatkan keterampilan berpikir kritis. Namun dengan nilai N-gain kelas eksperimen yang lebih tinggi diketahui bahwa peningkatan keterampilan berpikir kritis pada kelas eksperimen lebih baik dibanding kelas kontrol, sehingga dapat disimpulkan bahwa penerapan strategi peta konsep efektif terhadap keterampilan berpikir kritis siswa pada materi keanekaragaman hayati.
\end{abstract}

Kata Kunci: Keanekaragaman hayati; keterampilan berpikir kritis; strategi peta konsep

\begin{abstract}
This quasi-experimental aims to investigate the effectiveness of concept mapping strategy on the critical thinking skill of year X students at MAN 1 Kendari. Using non-randomized pretest-posttest control group design, this study utilized inventory's sheet of critical thinking skill, test for critical thinking skill and the concept mapping analysis. The control class was taught
\end{abstract}


by using conventional strategy, while the experiment class used the concept mapping strategy. The result indicates the significant gain score of students' pretest-posttest average score. In the test of critical thinking skill, control class has improved up to 0,28, meanwhile the experiment class taking up to 0,38, with the significance score is 0,029. This study shows that the implementation of concept mapping strategy does not significantly affect the students' critical thinking skill. However, by looking at the gain score from experimental class, which is higher than the control class, the students' critical thinking skill can be developed better using the concept mapping strategy, especially in biodiversity lesson.

Keywords: Biodiversity; concept mapping strategy; critical thinking skill

\section{A. PENDAHULUAN}

Proses pembelajaran merupakan inti proses pendidikan dimana guru sebagai perancang dan siswa sebagai objek. Keberhasilan suatu pembelajaran ditentukan oleh banyak faktor seperti kualitas guru dalam penguasaan materi, strategi pembelajaran, metode evaluasi, desain pembelajaran, dan kesiapan siswa. Setiap guru berfungsi sebagai perancang pengajaran, yaitu guru dapat merancang kegiatan pembelajaran yang berdaya guna; pengelola pengajaran, yaitu guru mengelola tahapan proses pembelajaran; dan penilai prestasi belajar siswa, yaitu guru dapat mengikuti kemajuan prestasi belajar dan kinerja akademik siswa. Saat ini, tugas guru tidak hanya memberikan ilmu pengetahuan pada siswa, tetapi juga melatih keterampilan dan karakter siswa.

Proses pendidikan di Indonesia saat ini dikatakan masih belum berhasil. Beberapa hasil survei dari The Political and Economic Risk Consultancy (PERC) yang dimuat oleh The Jakarta Post (3 September 2001) menunjukkan bahwa kualitas pendidikan di Indonesia masih rendah jika dibanding negara lain di Asia (Mulyasa, 2005). Dari kegiatan The Third International Mathematics and Science Study yang diikuti oleh 38 negara pada tahun 2011 diketahui bahwa prestasi siswa SMA kelas X di Indonesia pada mata pelajaran IPA (biologi, fisika, geografi, kimia) berada pada urutan ke-36 (Provasnik, Katsberg, Ferraro, Lemanski, Roey, \& Jenkins, 2012), sehingga prestasi mereka mutlak dikembangkan guna menghasilkan siswa yang berkualitas dan mampu menghadapi era globalisasi. Salah satu hal yang bisa dilakukan adalah dengan memperbaiki proses pembelajaran di kelas pada mata pelajaran IPA.

Proses pembelajaran IPA, khususnya biologi, saat ini masih berpusat pada guru dan siswa cenderung pasif, serta masih banyak berfokus pada pembelajaran konsep dan hafalan yang tidak menekankan penggunaan dan pengembangan keterampilan proses dan sikap ilmiah siswa. Kegiatan pembelajaran hanya menekankan pemahaman pada keterampilan berpikir 
tingkat dasar, belum memaksimalkan keterampilan berpikir yang dapat mendukung siswa untuk memahami materi, memberikan ide/gagasan, dan mengaplikasikannya, sehingga konsep biologi (khususnya pada konsep keanekaragaman hayati) yang diajarkan tidak dapat dipahami dengan baik karena siswa cenderung hanya ingin mengetahui.

Marzano (dalam Sidharta, 2005) menyatakan keterampilan berpikir sebagai habits of mind, yang digunakan sebagai respon terhadap pertanyaan dan jawaban masalah yang tidak segera diketahui, sehingga guru dapat mengobservasi bagaimana siswa menghasilkan sebuah pengetahuan daripada hanya mengingat pengetahuan. Salah satu keterampilan berpikir yang harus dikembangkan guru dalam proses pembelajaran adalah keterampilan berpikir kritis. Selain itu, pemahaman konsep pembelajaran biologi mempunyai makna dapat mengkomunikasikan definisi konsep biologi dengan argumen sendiri, mampu memikirkan konsep dalam konteks umum, dan hubungannya dengan konsep yang lain. Untuk mengetahui dan memahami konsep biologi secara mendalam, maka keterampilan berpikir kritis harus dikembangkan.

Salah satu upaya yang dapat dilakukan untuk meningkatkan keterampilan berpikir kritis siswa tentang keanekaragaman hayati adalah pelibatan siswa secara langsung dalam pembelajaran dengan penggunaan strategi pembelajaran peta konsep, yang mendorong siswa untuk terlibat secara fisik dan intelektual dalam proses pembelajaran sehingga siswa dapat mengekspresikan diri baik dalam konteks ilmiah. Peta konsep adalah ilustrasi grafis konkrit yang mengindikasikan bagaimana sebuah konsep tunggal dihubungkan ke konsep lain pada kategori yang sama. Berdasarkan hal tersebut, maka peta konsep disusun secara hirarki. Artinya, konsep yang lebih inklusif diletakkan pada puncak peta, makin ke bawah konsep-konsep diurutkan menjadi konsep yang kurang inklusif. Dalam prosesnya, peta konsep mampu membuat informasi abstrak menjadi konkrit dan sangat bermanfaat meningkatkan keterampilan berpikir kritis siswa (Harmin \& Toth, 2012).

Bahtiar (2014) menyatakan bahwa ada perbedaan peningkatan yang signifikan terhadap motivasi belajar dan pemahaman konsep antara peserta didik yang mengikuti pembelajaran strategi peta konsep dan strategi dengan pengajaran langsung dalam pembelajaran biologi di kelas XII SMA Negeri 1 Kendari. Dalam penelitiannya, diketahui bahwa strategi peta konsep yang diberikan oleh guru mampu menggerakkan keinginan siswa untuk belajar secara serius agar dapat memahami konsep karena hasil yang baik yang akan diperoleh siswa berbanding lurus dengan pemahaman terhadap peta konsep yang disimaknya.

Dipihak lain, Pasuloi (2014) menyatakan bahwa model pembelajaran generatif dapat meningkatkan keterampilan berpikir kritis dan pemahaman konsep tekanan pada zat cair siswa kelas VIII SMP Negeri 12 Kendari. 
Dalam penelitiannya dijelaskan bahwa keterampilan berpikir kritis sangat penting untuk dikembangkan pada siswa agar mereka terbiasa mencari dan melengkapi pengetahuan sehingga mereka mampu memahami materi pembelajaran dengan lebih baik. Oleh karena itu, dapat dikatakan bahwa keterampilan berpikir kritis dan pemahaman konsep menjadi indikator penting yang harus dimiliki dan dikembangkan oleh siswa. Semua itu bisa tercapai jika seorang guru mampu memilih pendekatan, model, strategi, maupun metode pembelajaran yang tepat sesuai dengan materi yang akan diajarkan.

Berdasarkan uraian di atas dapat diketahui bahwa tujuan penelitian ini adalah mengetahui efektivitas dan signifikansi penerapan strategi peta konsep terhadap keterampilan berpikir kritis siswa di kelas X MAN 1 Kendari pada materi keanekaragaman hayati. Manfaat teoritis dari penelitian ini yaitu sebagai bahan pengembangan ilmu pengetahuan. Hasil penelitian diharapkan dapat memberi sumbangan pada perkembangan ilmu pendidikan, terutama pada penerapan strategi pembelajaran untuk meningkatkan keterampilan berpikir dan pemahaman konsep siswa. Sedangkan manfaat praktis dari penelitian ini, yaitu sebagai bahan masukan kepada pihak yang memerlukan untuk perbaikan kinerja dan sebagai informasi bahwa strategi peta konsep dapat meningkatkan keterampilan berpikir kritis dan pemahaman konsep siswa. Hasil penelitian ini juga diharapkan dapat membantu memperbaiki dan meningkatkan mutu pembelajaran biologi di kelas sehingga materi pelajaran ini dapat dipahami dengan baik oleh siswa. Selain itu, hasil penelitian ini juga menjadi masukan dalam upaya peningkatan kualitas pembelajaran maupun sebagai rujukan dan pembanding dalam menerapkan strategi peta konsep pada materi biologi yang lain.

\section{B. METODE PENELITIAN}

Penelitian ini menggunakan non randomized pretest-posttest control grup design yang nampak sebagai berikut.

$\underline{\mathrm{O}}_{1} \frac{\mathrm{G}_{1}}{\mathrm{O}_{3}}-\mathrm{O}_{2}-\frac{\mathrm{O}_{2}}{2}-\mathrm{O}_{4}$

(Wiersma, 1995: 149)

Keterangan:

$\mathrm{O}_{1}=$ Keterampilan berpikir kritis sebelum diajar dengan menerapkan strategi peta konsep

$\mathrm{O}_{2}=$ Keterampilan berpikir kritis setelah diajar dengan menerapkan strategi peta konsep

$\mathrm{O}_{3}=$ Keterampilan berpikir kritis sebelum diajar dengan menerapkan strategi konvensional

$\mathrm{O}_{4}=$ Keterampilan berpikir kritis setelah diajar dengan menerapkan strategi konvensional

$\mathrm{G}_{1}=$ Pemberian strategi peta konsep

$\mathrm{G}_{2}=$ Pemberian strategi konvensional 
Jenis data yang ada dalam penelitian ini adalah data kuantitatif dan data interval. Data kuantitatif ada pada data keterampilan berpikir kritis dan data pemahaman konsep yaitu berbentuk angka sehingga dapat diterapkan suatu operasi matematika. Sedangkan data interval ada pada data keterampilan berpikir kritis, yaitu data hasil pengukuran yang dapat diurutkan atas dasar kriteria tertentu (Sangadji, 2010).

Penelitian ini menggunakan dua teknik pengumpulan data sebagai berikut. Pertama, observasi yang dilakukan dengan menggunakan lembar observasi yang ditujukan untuk mengamati keterampilan berpikir kritis siswa dan penilaian terhadap peta konsep hasil buatan siswa. Kedua, dokumentasi yang dilakukan dengan melampirkan tahapan pembuatan peta konsep terbimbing dari guru kepada siswa, dan mengumpulkan hasil kerja peta konsep buatan setiap siswa.

Instrumen yang digunakan dalam penelitian ini adalah lembar inventory kemampuan berpikir kritis, dan analisis peta konsep. Instrumen keterampilan berpikir kritis siswa menggunakan lembar observasi, sedangkan instrumen penilaian peta konsep buatan siswa diadaptasi dari Brown dan Ferrara (1985) dalam bentuk rating scale. Sistem penilaian didasarkan pada kesesuaian dan ketepatan jawaban yang diberikan oleh siswa.

Data penelitian ini dianalisis dengan menggunakan analisis statistik deskriptif dan inferensial. Analisis deskriptif digunakan untuk menggambarkan data penelitian dalam bentuk mean (rata-rata), standar deviasi, persentase, serta kriteria tingkat keterampilan berpikir kritis siswa. Sedangkan analisis inferensial digunakan aplikasi software SPSS 20.0 untuk mengetahui dan menguji hipotesis melalui uji independent sample t-test. Selanjutnya, menentukan tingkat keterampilan berpikir kritis dan pemahaman konsep siswa digunakan kategori sebagai berikut.

Kategori sudah berkembang:

$\mathrm{Xi} \geq \bar{x}+\mathrm{SD}$

Kategori berkembang:

$\bar{x}-\mathrm{SD}<\mathrm{Xi}<\bar{x}+\mathrm{SD}$

Kategori belum berkembang:

$\mathrm{Xi} \leq \bar{x}-\mathrm{SD}$

Keterangan:

$\mathrm{Xi} \quad=$ Nilai siswa ke-i

$\bar{x} \quad=$ Nilai rerata

$\mathrm{SD}=$ Standar Deviasi

(Sudjana, 2002: 112)

\section{HASIL DAN PEMBAHASAN}

Data yang dikumpulkan dalam penelitian ini adalah nilai siswa yang diperoleh dari tes Keterampilan Berpikir Kritis (KBK), lembar observasi 
keterampilan berpikir kritis, dan kriteria penilaian peta konsep buatan siswa selama pembelajaran dengan strategi konvensional dan strategi peta konsep, yang telah dianalisis secara deskriptif dan inferensial. Pada penelitian ini, kelas kontrol merupakan kelas $\mathrm{X}_{8}$ yang menggunakan strategi konvensional, sedangkan kelas eksperimen merupakan kelas $\mathrm{X}_{9}$ yang menggunakan strategi peta konsep.

\section{Analisis Deskriptif \\ Distribusi nilai KBK siswa}

Distribusi nilai yang dimaksud dalam penelitian ini yaitu nilai $\mathrm{N}$-Gain dari pretest dan posttest keterampilan berpikir kritis materi keanekaragaman hayati yang dilakukan di kelas kontrol maupun di kelas eksperimen, yang disajikan pada Tabel 1 berikut.

Tabel 1. Perbandingan nilai hasil tes keterampilan berpikir kritis kelas kontrol dan kelas

\begin{tabular}{lclccll}
\hline \multirow{2}{*}{ Statistik } & $\begin{array}{l}\text { Pretest } \\
\text { KBK } \\
\text { Kontrol }\end{array}$ & $\begin{array}{l}\text { Pretest } \\
\text { KBK Eks. }\end{array}$ & $\begin{array}{l}\text { Posttest } \\
\text { KBK } \\
\text { Kontrol }\end{array}$ & $\begin{array}{l}\text { Posttest } \\
\text { KBK Eks. }\end{array}$ & $\begin{array}{l}\text { N-Gain } \\
\text { KBK } \\
\text { Kontrol }\end{array}$ & $\begin{array}{l}\text { N-Gain } \\
\text { KBK Eks. }\end{array}$ \\
& 27,82 & 27,73 & 47,82 & 54,76 & 0,28 & 0,38 \\
Mean & 28,89 & 24,44 & 48,89 & 53,33 & 0,29 & 0,37 \\
Median & 31,11 & 22,22 & 48,89 & 64,44 & 0,29 & 0,45 \\
Mode & 12,85 & 9,71 & 12,12 & 9,45 & 0,06 & 0,07 \\
Std. Deviation & 165,07 & 94,27 & 146,94 & 89,23 & 0,004 & 0,004 \\
Variance & 6,67 & 6,67 & 26,67 & 31,11 & 0,17 & 0,26 \\
Minimum & 61,11 & 44,44 & 73,33 & 73,33 & 0,45 & 0,54 \\
Maximum & $\mathbf{6 9 5 , 5 4}$ & $\mathbf{6 9 3 , 3 3}$ & $\mathbf{1 1 9 5 , 5 6}$ & $\mathbf{1 3 6 8 , 8 8}$ & $\mathbf{7 , 0 1}$ & $\mathbf{9 , 4 4}$ \\
\hline Sum & $\mathbf{6 9 5}$ & & & & & \\
\hline
\end{tabular}

Tabel 1 menunjukkan bahwa nilai rerata pretest keterampilan berpikir kritis kedua kelas adalah hampir sama, yaitu 27,82 pada kelas kontrol dan 27,73 pada kelas eksperimen. Namun, terjadi peningkatan yang signifikan pada kelas eksperimen setelah melalui penerapan strategi peta konsep menjadi 54,58 dan terjadi peningkatan pada kelas kontrol setelah melalui penerapan strategi konvensional menjadi 47,82. Selanjutnya, kebermaknaan peningkatan dari nilai rerata pretest dan posttest diwakili oleh skor $\mathrm{N}$-gain siswa. Kelas kontrol mengalami peningkatan sebesar 0,28 sedangkan kelas eksperimen mengalami peningkatan sebesar 0,38. Secara grafik, dapat dilihat pada Gambar 1 berikut. 


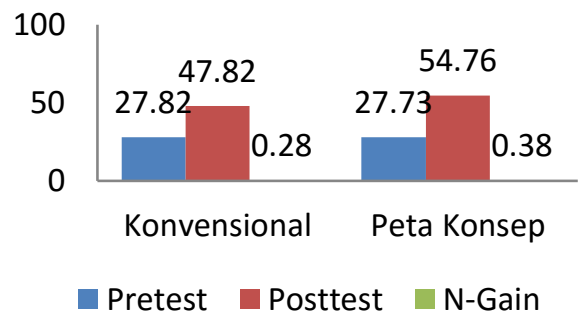

Gambar 1. Perbandingan distribusi nilai KBK siswa

\section{Interpretasi tingkat KBK siswa}

Interpretasi yang dimaksud dalam hasil penelitian ini yaitu berupa perbedaan tingkat KBK di kelas kontrol maupun di kelas eksperimen yang terkategori sudah berkembang, berkembang, dan belum berkembang, dengan interval kelas tertentu. Interpretasi hasil penelitian disajikan pada Tabel 2 berikut.

Tabel 2. Kategori keterampilan berpikir kritis siswa pada kelas kontrol dan kelas eksperimen

\begin{tabular}{|c|c|c|c|c|c|c|c|}
\hline \multirow{2}{*}{$\begin{array}{l}\text { Kelas Kontrol } \\
\text { Interval Kelas }\end{array}$} & \multirow[b]{2}{*}{ Kategori } & \multirow[b]{2}{*}{$\mathbf{F}$} & \multirow[b]{2}{*}{$\%$} & \multicolumn{2}{|c|}{ Kelas Eksperimen } & \multirow[b]{2}{*}{$\mathbf{F}$} & \multirow[b]{2}{*}{$\%$} \\
\hline & & & & Interval Kelas & Kategori & & \\
\hline $\mathrm{Xi} \geq 59.94$ & $\begin{array}{l}\text { Sudah } \\
\text { berkembang }\end{array}$ & 4 & 16 & $\mathrm{Xi} \geq 64.21$ & $\begin{array}{l}\text { Sudah } \\
\text { berkembang }\end{array}$ & 7 & 28 \\
\hline $\begin{array}{l}35.70<\mathrm{Xi}< \\
59.94\end{array}$ & Berkembang & 15 & 60 & $\begin{array}{l}45.31<\mathrm{Xi}< \\
64.21\end{array}$ & Berkembang & 16 & 64 \\
\hline $\mathrm{Xi} \leq 35.7$ & $\begin{array}{l}\text { Belum } \\
\text { berkembang }\end{array}$ & 6 & 24 & $\mathrm{Xi} \leq 45.31$ & $\begin{array}{l}\text { Belum } \\
\text { berkembang }\end{array}$ & 2 & 8 \\
\hline Jumlah & & 25 & 100 & Jumlah & & 25 & 100 \\
\hline
\end{tabular}

Tabel 2 menunjukkan bahwa terdapat perbedaan persentase tingkat keterampilan berpikir kritis siswa di kelas kontrol dan kelas eksperimen. Pada kategori sudah berkembang, persentase jumlah siswa kelas kontrol sebanyak 28\% dan kelas eksperimen sebanyak 16\%. Pada kategori berkembang, persentase jumlah siswa kelas kontrol sebanyak $60 \%$ dan kelas eksperimen sebanyak 64\%. Pada kategori belum berkembang, persentase jumlah siswa kelas kontrol sebanyak $24 \%$ dan kelas eksperimen sebanyak $8 \%$. Secara grafik, dapat dilihat pada Gambar 2 berikut. 

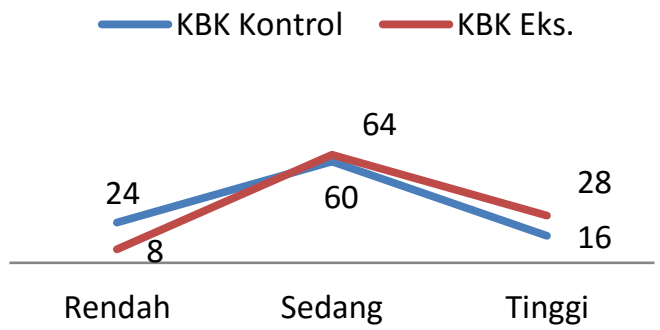

Gambar 2. Perbandingan interpretasi tingkat KBK siswa

\section{Observasi KBK siswa}

Interpretasi data yang dimaksud dalam penelitian ini yaitu berupa skor penilaian 10 aspek keterampilan berpikir kritis siswa selama kegiatan pembelajaran, baik di kelas kontrol maupun di kelas eksperimen. Kesepuluh aspek tersebut meliputi 1) memfokuskan pertanyaan; 2) menganalisis pertanyaan dan bertanya balik; 3) menjawab pertanyaan dengan suatu penjelasan; 4) mempertimbangkan keakuratan sumber dan mengamati laporan hasil pengamatan; 5) mendeduksi dan mempertimbangkan hasil deduksi; 6) menginduksi dan mempertimbangkan hasil induksi; 7) membuat serta menentukan nilai pertimbangan; 8) mengidentifikasi istilah-istilah dan definisi;(9) Memberikan asumsi pemecahan suatu masalah; dan 10) menentukan tindakan dan berinteraksi dengan orang lain. Interpretasi data observasi keterampilan berpikir kritis siswa selama kegiatan pembelajaran pada kelas kontrol dan kelas eksperimen disajikan pada Tabel 3 berikut.

Tabel 3. Interpretasi observasi keterampilan berpikir kritis siswa kelas kontrol

\begin{tabular}{crrrrrrrrrrrc}
\hline \multirow{2}{*}{ Pertemuan } & \multicolumn{1}{c}{ Indikator } & \multicolumn{3}{c}{ Jumlah } & \% \\
& $\mathbf{1}$ & $\mathbf{2}$ & $\mathbf{3}$ & $\mathbf{4}$ & $\mathbf{5}$ & $\mathbf{6}$ & $\mathbf{7}$ & $\mathbf{8}$ & $\mathbf{9}$ & $\mathbf{1 0}$ & Skor & \\
\hline 1 & 66 & 64 & 55 & 50 & 12 & 10 & 8 & 49 & 48 & 43 & 405 & 54 \\
2 & 65 & 64 & 55 & 50 & 32 & 24 & 10 & 53 & 47 & 42 & 442 & 58,9 \\
3 & 65 & 64 & 55 & 50 & 38 & 31 & 20 & 55 & 48 & 42 & 468 & 62,4 \\
4 & 65 & 64 & 55 & 50 & 40 & 31 & 26 & 57 & 49 & 42 & 479 & 63,9 \\
\hline Jumlah & $\mathbf{2 6 0}$ & $\mathbf{2 5 6}$ & $\mathbf{2 2 0}$ & $\mathbf{2 0 0}$ & $\mathbf{1 2 2}$ & $\mathbf{9 6}$ & $\mathbf{6 4}$ & $\mathbf{2 1 4}$ & $\mathbf{1 9 2}$ & $\mathbf{1 6 9}$ & & \\
\hline
\end{tabular}

Berdasarkan data pada Tabel 3, diketahui bahwa persentase keterampilan berpikir kritis siswa kelas kontrol selalu mengalami peningkatan di tiap pertemuannya, yaitu $54 \%$ pada pertemuan pertama menjadi $63,9 \%$ pada pertemuan keempat. Selama empat kali pertemuan diketahui aspek-aspek keterampilan berpikir kritis siswa yang rendah maupun yang tinggi. Aspek terendah adalah membuat serta menentukan nilai pertimbangan sebesar 64 poin, dan aspek tertinggi adalah memfokuskan pertanyaan sebesar 260 poin. 
Interpretasi data observasi keterampilan berpikir kritis siswa selama kegiatan pembelajaran pada kelas eksperimen disajikan pada Tabel 4 berikut.

Tabel 4. Hasil observasi keterampilan berpikir kritis siswa kelas eksperimen

\begin{tabular}{ccccccccccccc}
\hline \multirow{2}{*}{ Pertemuan } & \multicolumn{1}{c}{} & $\mathbf{1}$ & $\mathbf{9}$ & $\mathbf{1 n d i k a t o r}$ & \multicolumn{3}{c}{ Jumlah } & \% \\
& $\mathbf{1}$ & $\mathbf{2}$ & $\mathbf{3}$ & $\mathbf{4}$ & $\mathbf{5}$ & $\mathbf{6}$ & $\mathbf{7}$ & $\mathbf{8}$ & $\mathbf{9}$ & $\mathbf{1 0}$ & Skor & \\
\hline 1 & 66 & 64 & 55 & 50 & 33 & 21 & 8 & 49 & 48 & 43 & 437 & 58,3 \\
2 & 66 & 64 & 58 & 52 & 35 & 25 & 16 & 49 & 48 & 43 & 456 & 60,8 \\
3 & 72 & 70 & 62 & 52 & 37 & 25 & 19 & 54 & 50 & 44 & 485 & 64,7 \\
4 & 75 & 74 & 65 & 52 & 38 & 31 & 25 & 61 & 52 & 45 & 518 & 69,1 \\
\hline Jumlah & $\mathbf{2 7 9}$ & $\mathbf{2 7 2}$ & $\mathbf{2 4 0}$ & $\mathbf{2 0 6}$ & $\mathbf{1 4 3}$ & $\mathbf{1 0 2}$ & $\mathbf{6 8}$ & $\mathbf{2 1 3}$ & $\mathbf{1 9 8}$ & $\mathbf{1 7 5}$ & & \\
\hline
\end{tabular}

Berdasarkan data Tabel 4 diketahui bahwa persentase keterampilan berpikir kritis siswa kelas eksperimen selalu mengalami peningkatan di tiap pertemuannya, yaitu $58,3 \%$ pada pertemuan 1 menjadi $69,1 \%$ pada pertemuan keempat. Selama empat kali pertemuan diketahui aspek-aspek keterampilan berpikir kritis siswa yang rendah maupun yang tinggi. Aspek terendah yaitu membuat serta menentukan nilai pertimbangan sebesar 68 poin, dan aspek tertinggi yaitu memfokuskan pertanyaan sebesar 279 poin.

Perbandingan persentase skor observasi keterampilan berpikir kritis siswa pada kelas kontrol dan kelas eksperimen disajikan pada Gambar 3 berikut.

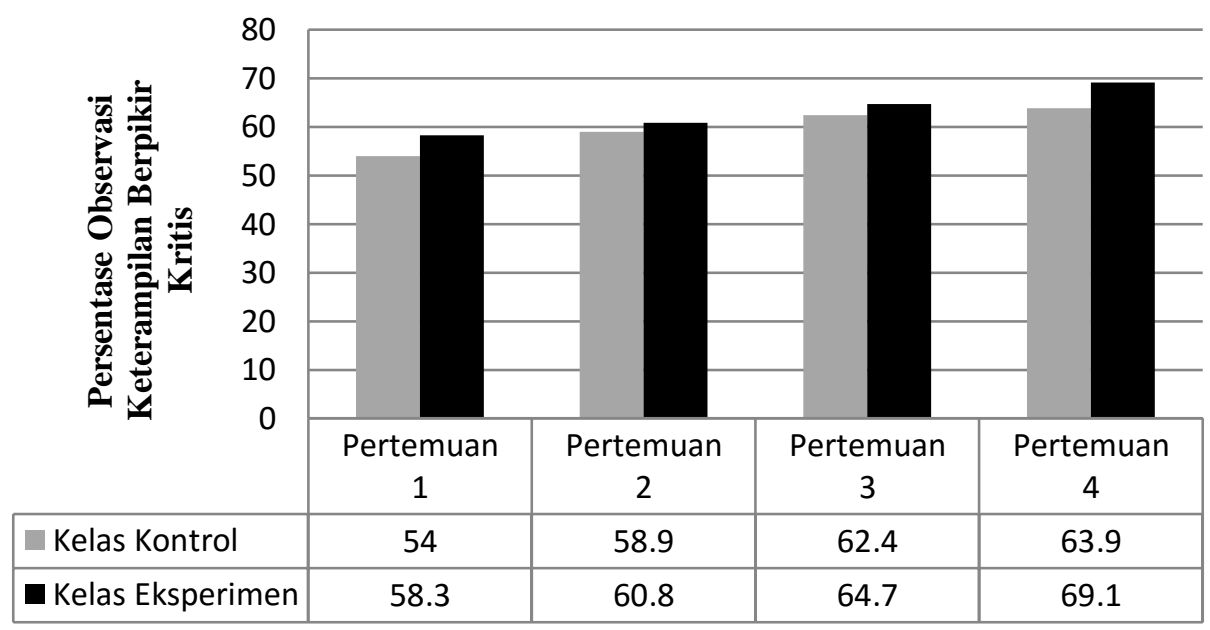

Gambar 3. Perbandingan persentase skor observasi keterampilan berpikir kritis siswa

Berdasarkan Gambar 3 dapat dikatakan bahwa keterampilan berpikir kritis siswa kelas kontrol dan kelas eksperimen mengalami peningkatan selama kegiatan pembelajaran. Namun dilihat dari persentasenya, 
peningkatan keterampilan berpikir kritis selama kegiatan pembelajaran pada kelas eksperimen lebih baik dibanding peningkatan keterampilan berpikir kritis selama kegiatan pembelajaran pada kelas kontrol.

\section{Interpretasi penilaian peta konsep buatan siswa}

Interpretasi data yang dimaksud yaitu berupa skor penilaian 3 aspek penyusunan peta konsep buatan siswa selama kegiatan pembelajaran pada kelas eksperimen. 3 aspek tersebut adalah (1) proposisi; (2) hirarki; dan (3) cross link. Interpretasi penilaian peta konsep buatan siswa selama kegiatan pembelajaran pada kelas eksperimen disajikan pada Tabel 5 berikut.

Tabel 5. Interpretasi penilaian peta konsep buatan siswa

\begin{tabular}{|c|c|c|c|c|c|c|c|}
\hline \multirow{2}{*}{ No } & \multirow{2}{*}{ Aspek yang dinilai } & \multicolumn{4}{|c|}{ Pertemuan } & \multirow[b]{2}{*}{$\sum$} & \multirow{2}{*}{$\%$} \\
\hline & & 1 & 2 & 3 & 4 & & \\
\hline 1 & Proposisi & 7 & 9 & 9 & 10 & 35 & 87,5 \\
\hline 2 & Hirarki & 13 & 18 & 21 & 23 & 75 & 75 \\
\hline 3 & Cross link & 5 & 10 & 10 & 10 & 35 & 17,5 \\
\hline
\end{tabular}

Berdasarkan Tabel 5 diketahui bahwa persentase peta konsep buatan siswa dari pertemuan pertama sampai pertemuan keempat mengalami peningkatan, yaitu $29,41 \%$ pada pertemuan 1 menjadi $50,59 \%$ pada pertemuan keempat. Selain itu, diketahui pula aspek yang masih kurang maupun yang sudah dipahami oleh siswa dalam pembuatan peta konsep selama empat kali pertemuan. Aspek yang sudah dipahami siswa adalah proposisi sebesar $87,50 \%$ dan hirarki sebesar $75,00 \%$, dan aspek yang kurang dipahami siswa adalah cross link sebesar 17,50\%.

\section{Analisis Diferensial \\ Uji normalitas data}

Uji normalitas yang digunakan dalam analisis data penelitian adalah analisa grafik P-Plot yang menampilkan titik-titik bulat yang merupakan simbol dari data tiap distribusi. Selanjutnya, titik-titik bulat tersebut akan berada di sekitar garis lurus. Jika titik-titik tersebut mendekati garis lurus maka diasumsikan bahwa data berdistribusi normal. Begitu pula sebaliknya, berdasarkan grafik terlampir dapat disimpulkan bahwa data berdistribusi normal karena semua titik mendekati garis lurus sehingga uji homogenitas dapat dilanjutkan.

\section{Uji homogenitas dan uji hipotesis}

Uji homogenitas dan hipotesis varians data penelitian ini menggunakan uji independent sample t-test karena kedua jenis sampel tidak berikatan (berhubungan) atau saling bebas. Artinya, kejadian yang ada pada sampel satu belum tentu terjadi pada sampel dua. Pada uji homogenitas kemampuan 
berpikir kritis diketahui bahwa nilai signifikansi sebesar 0,353. Berdasarkan kriteria uji maka dapat dikatakan bahwa $\mathrm{H}_{0}$ diterima karena nilai signifikansinya $(0,353)$ lebih besar dibanding nilai $\alpha(0,05)$. Artinya, kemampuan berpikir kritis siswa di kedua kelas mempunyai varians yang homogen sehingga uji hipotesis dapat dilanjutkan. Pada uji hipotesis keterampilan berpikir kritis diketahui bahwa nilai signifikansi 0,029. Berdasarkan kriteria uji maka dapat dikatakan bahwa $\mathrm{H}_{0}$ diterima karena nilai signifikansi lebih besar dibanding nilai $\alpha / 2$. Artinya, tidak ada perbedaan yang signifikan antara keterampilan berpikir kritis kelas kontrol dan kelas eksperimen. Data uji homogenitas dan uji hipotesis keterampilan berpikir kritis siswa materi keanekaragaman hayati disajikan pada Tabel 6 berikut.

Tabel 6. Nilai propabilitas uji homogenitas dan uji hipotesis keterampilan berpikir kritis siswa materi keanekaragaman hayati

\begin{tabular}{lclr}
\hline \multicolumn{1}{c}{ Nilai } & KBK & \multicolumn{1}{c}{ Keterangan } & PK \\
\hline Sig. Homogenitas & 0,353 & Varians homogen & 0,051 \\
Sig. Hipotesis & 0,029 & Tidak ada perbedaan yang signifikan antara & 0,017 \\
& & $\begin{array}{l}\text { keterampilan berpikir kritis kelas kontrol dan } \\
\text { kelas eksperimen }\end{array}$ & \\
\hline
\end{tabular}

\section{Pembahasan}

Penggunaan strategi peta konsep sangat efektif digunakan guru untuk membantu siswa mengorganisasikan konsep pelajaran yang telah dipelajari berdasarkan arti dan hubungan antara komponennya. Kaitan konsep yang satu dengan konsep yang lain merupakan hal yang penting dalam belajar sehingga apa yang dipelajari oleh siswa akan lebih bermakna, lebih mudah diingat dan dipahami, diolah serta dikeluarkan kembali (Kardi, 2003). Oleh karena itu, jika siswa menyusun sendiri peta konsep sebelum pembelajaran dimulai maka akan membantu mereka menguasai dan memahami materi yang akan dipelajari.

Materi biologi khususnya keanekaragaman hayati memiliki berbagai konsep yang harus dipelajari. Akan tetapi, penggunaan nama-nama ilmiah dan proses yang abstrak pada konsep ini membuat siswa mengalami kesulitan dalam mempelajarinya yang berdampak pada kurangnya pemahaman dan seringnya tejadi kesalahan konsepsi siswa (Sutowijoyo, 2002). Pada bagian pembahasan ini diuraikan tentang efektivitas penggunaan strategi peta konsep pada materi keanekaragaman hayati yang ditinjau dari keterampilan berpikir kritis siswa.

Proses pembelajaran yang berlangsung di kedua kelas (kontrol dan eksperimen) pada awalnya tidak menunjukan adanya perbedaan yang menonjol. Siswa sebagian besar belum siap untuk mengikuti pelajaran. Ini dapat dilihat dari pengetahuan awal tentang materi yang akan diajarkan. Siswa kurang aktif dan hanya mengharapkan informasi dari guru sehingga 
tidak termotivasi untuk belajar. Pada kedua kelas tersebut siswa nampak belum memahami dan tidak terbiasa dengan permasalahan yang diberikan peneliti sehingga apabila terdapat soal dari lembar kerja siswa yang membutuhkan suatu analisis, siswa hanya menjawab dengan menyalin jawaban dari siswa yang lain.

Lionor dalam Khalili, Babamohammadi, dan Hajiaghajani (2003) menyatakan bahwa aktivitas kognitif dan upaya sistematis mental untuk memahami dan memeriksa temuan dan fenomena dan hubungan mereka berdasarkan keterampilan penalaran dan analisis merupakan salah satu bentuk berpikir kritis. Selain itu, hasil penelitian Wright dan Bar, Sartorelli, Swartz dan Parks dalam Hassoubah (2004) menunjukkan bahwa beberapa cara meningkatkan keterampilan berpikir kritis diantaranya adalah dengan meningkatkan daya analisis. Oleh karena itu, siswa yang tidak terbiasa dengan permasalahan yang menuntut penalaran dan analisis maka akan sulit berpikir kritis.

Lebih lanjut, Wilingham (2007) dalam jurnalnya menjelaskan bahwa biasanya para siswa ketika fokus pada permasalahan hanya pada struktur permukaannya bukan pada struktur yang mendalam untuk menyelesaikannya. Jadi, meskipun siswa telah diajarkan bagaimana memecahkan suatu jenis masalah, ketika terjadi perubahan masalah dari guru atau dari sebuah buku makamereka masih harus berjuang untuk menerapkan solusi karena mereka tidak memahami bahwa pada dasarnya masalah tersebut secara matematis sama.

Berdasarkan analisis deskriptif data yang diperoleh melalui hasil tes keterampilan berpikir kritis siswa diketahui bahwa terjadi peningkatan keterampilan berpikir kritis pada kelas kontrol maupun kelas eksperimen. Namun nilai $\mathrm{N}$-gain (kebermaknaan peningkatan) kelas eksperimen sebesar 0,38 lebih tinggi dibanding $N$-gain kelas kontrol sebesar 0,28. Selain itu, terdapat perbedaan kategori keterampilan berpikir kritis antara siswa kelas kontrol dengan siswa kelas eksperimen. Persentase jumlah siswa dengan keterampilan berpikir kritis kategori belum berkembang di kelas eksperimen lebih sedikit dibanding kelas kontrol. Sedangkan persentase jumlah siswa dengan keterampilan berpikir kritis pada kategori berkembang dan sudah berkembang kelas eksperimen lebih banyak dibanding kelas kontrol.

Tingginya peningkatan keterampilan berpikir kritis di kelas eksperimen dikarenakan kelas eksperimen menggunakan strategi peta konsep yang menekankan perubahan pada keterampilan berpikir tingkat tinggi dalam kegiatan pembelajarannya sehingga siswa tidak lagi kesulitan merekonstruksi ide atau gagasan untuk memecahkan suatu permasalahan (Dahar, 1996). Selain itu, penggunaan strategi peta konsep juga dapat membantu siswa untuk lebih mudah mengetahui dan memahami materi yang diajarkan karena dalam strategi belajar peta konsep siswa dituntut bergerak untuk tahu. Slavin 
(dalam Pratiwi, 2003) menyatakan bahwa untuk menyusun suatu laporan atau untuk menjawab pertanyaan-pertanyaan suatu tes, siswa harus terlibat dalam proses-proses berpikir tingkat tinggi dan berperilaku. Untuk itu, dalam proses belajar diperlukan penerapan strategi belajar tertentu, salah satunya adalah strategi peta konsep. Uraian di atas menunjukkan bahwa setelah melalui penerapan strategi peta konsep, keterampilan berpikir kritis kelas eksperimen menjadi lebih baik dibanding keterampilan berpikir kritis kelas kontrol.

Hasil pengujian hipotesis yang dilakukan menunjukkan bahwa secara statistik nilai signifikansi untuk uji hipotesis yang dihasilkan sebesar 0,029 lebih besar dibanding nilai $\alpha / 2$ sebesar 0,025 sehingga $\mathrm{H}_{0}$ diterima. Artinya, tidak ada perbedaan keterampilan berpikir kritis siswa antara kelas yang menggunakan strategi konvensional dan strategi peta konsep. Namun, secara deskriptif nilai rerata posttest siswa pada kelas eksperimen sebesar 54,76 lebih baik dibanding nilai rerata posttest siswa di kelas kontrol sebesar 47,82. Nilai rerata posttest yang tinggi pada kelas eksperimen dikarenakan pemberian strategi peta konsep pada siswa kelas ini mampu meningkatkan peran aktif, kesiapan, pemahaman, dan penguasaan terhadap materi pelajaran biologi.

Selain itu, siswa pada kelas eksperimen saling bekerja sama dan bertukar gagasan yang aktif di dalam kelompok kecil sehingga tidak hanya menarik perhatian siswa tetapi juga dapat mempromosikan pemikiran kritis. Kerjasama dapat memberi kesempatan kepada siswa untuk terlibat dalam diskusi, bertanggung jawab terhadap pelajaran sehingga dengan begitu mereka menjadi pemikir yang kritis (Totten, Ambang, Digby, \& Russ dalam Gokhale, 2002). Oleh karena itu, jika didukung dengan keterlibatan siswa secara individu dalam pelaksanaan pembelajaran, maka akan dapat merangsang daya kritis dan analisis yang tinggi dari siswa sehingga dapat memecahkan masalah dari soal yang diberikan.

Keterampilan berpikir kritis perlu dikembangkan dalam diri siswa karena melalui keterampilan berpikir kritis siswa dapat lebih mudah memahami konsep, peka akan masalah yang terjadi sehingga dapat memahami, menyelesaikan, dan mengaplikasikan konsep dalam situasi yang berbeda. Namun dalam mengajarkan suatu konsep tertentu, harus dipilih strategi pembelajaran yang paling sesuai dengan tujuan yang akan dicapai untuk meningkatkan keterampilan berpikir kritis. Artinya, tidak semua strategi pembelajaran bisa diterapkan untuk meningkatkan keterampilan berpikir kritis, dan bukan berarti hanya strategi peta konsep yang mampu meningkatkan keterampilan berpikir kritis.

Berdasarkan analisis hasil observasi keterampilan berpikir kritis siswa pada setiap aspek penilaian menunjukkan bahwa aspek membuat serta menentukan nilai pertimbangan merupakan aspek yang kurang dipahami dan dilakukan siswa, sedangkan memfokuskan pertanyaan merupakan aspek yang 
mudah dipahami dan dilakukan siswa. Aspek membuat serta menentukan nilai pertimbangan merupakan hal baru yang harus dilakukan siswa dibanding aspek memfokuskan pertanyaan sehingga butuh waktu dan proses pemahaman yang lebih dari siswa untuk dapat meningkatkan aspek terendah tersebut. Ennis (1996) menyatakan bahwa memfokuskan pertanyaan merupakan aktivitas berpikir kritis pertama yang hanya menuntut siswa untuk dapat memberi pertanyaan berdasarkan penjelasan-penjelasan sederhana, sedangkan membuat serta menentukan nilai pertimbangan merupakan aktivitas ketiga sebagai titik balik dalam memulai mengasah keterampilan berpikir kritis siswa.

Namun secara klasikal, kelas eksperimen memiliki persentase yang lebih tinggi dibanding kelas kontrol. Siswa pada kelas eksperimen diberikan tanggung jawab dan pengalaman pribadi untuk membuat dan menyusun konsep berdasarkan pemahaman siswa sendiri sedangkan siswa di kelas kontrol hanya menyelesaikan permasalahan yang telah diberikan guru sebelumnya sehingga kurang mendorong siswa untuk melakukan proses menganalisis.

Strategi peta konsep berperan dalam membangun proses berpikir secara sistematis/ terstruktur sehingga proses pembelajaran tidak monoton dan tidak mengarah ke proses hafalan konsep. Struktur tersebut terbentuk karena siswa secara berkelompok maupun mandiri menemukan dan menyusun ide-ide kunci dari suatu materi ke dalam bentuk hirarki. Kondisi ini membuat konsep-konsep tersusun secara sistematis dari hal yang umum ke hal yang khusus. Hasil penelitian ini sejalan dengan Iskandar (2009) yang menyatakan bahwa keberhasilan siswa dalam mengkonstruk konsep/ substansi suatu materi dapat dilakukan dengan menggunakan strategi peta konsep. Selain itu, peta konsep juga menyebabkan terjadinya serangkaian interaksi yang baik antara siswa dengan guru dalam rangka mencapai tujuan pembelajaran sehingga dapat disimpulkan bahwa penggunaan strategi peta konsep efektif dan signifikan dalam meningkatkan pemahaman konsep dibanding strategi konvensional.

Berdasarkan analisis peta konsep buatan siswa pada setiap aspek penilaian, hasil penelitian menunjukkan bahwa aspek proposisi merupakan aspek yang mudah dipahami dan dilakukan siswa, sedangkan cross link merupakan aspek yang kurang dipahami dan dilakukan siswa. Aspek proposisi merupakan tahap awal dari pembuatan peta konsep yang hanya menuntut siswa untuk dapat menghubungkan dua atau lebih konsep. Sedangkan cross link merupakan tahap terakhir dari pembuatan peta konsep yang menuntut siswa untuk dapat mengaitkan hubungan bermakna antara konsep pada satu hirarki dengan konsep lain pada hirarki lainnya. Ditahap ini, siswa harus memiliki pengetahuan dan pemahaman lebih dari suatu konsep untuk dapat membuat suatu cross link. Novak dan Canas (2008) 
menyatakan bahwa karakteristik dan terpenting dalam meningkatkan pemahaman konsep siswa adalah cross link, dimana cross link sering mewakili lompatan kreatif sebagai bagian dari peningkatan keterampilan berpikir kreatif dan kritis dalam menciptakan pengetahuan dan pemahaman baru.

Kondisi demikian membuat siswa harus berkolaborasi dengan teman sekelompoknya dalam menentukan cross link konsep ataupun kata-kata kunci yang dibutuhkan dalam membentuk peta konsep yang baik dan benar. Eliyanti (2013) menyatakan bahwa siswa dituntut untuk dapat saling berbagi ide dan tanggung jawab, serta belajar untuk menerima pendapat dan saran teman sekelompoknya dalam membuat peta konsep sehingga berperan penting meningkatkan respon siswa dalam mengkonstruk konsep yang sedang dipelajarinya dan siswa menjadi lebih mudah memahami konsep, lebih mandiri, serta menganggap pembelajaran tidak membosankan sehingga berminat mengikuti pembelajaran.

\section{PENUTUP}

Berdasarkan hasil penelitian dan pembahasan, maka dapat ditarik suatu simpulan bahwa secara statistik, tidak ada perbedaan yang signifikan antara strategi peta konsep dan strategi konvensional dalam meningkatkan keterampilan berpikir kritis siswa di kelas X pada materi keanekaragaman hayati. Namun secara deskriptif, penerapan strategi peta konsep efektif dibanding strategi konvensional dalam meningkatkan keterampilan berpikir kritis siswa pada materi keanekaragaman hayati.

\section{E. DAFTAR PUSTAKA}

Bahtiar. (2014). Penerapan strategi concept map untuk meningkatkan pemahaman konsep dan memperbaiki miskonsepsi siswa pada materi sistem ekskresi manusia. Tesis tidak dipublikasikan. Kendari: Program Pascasarjana Universitas Halu Oleo.

Brown, A. L., \& Ferrara, R. A. (1985). Diagnosing zones of proximal development: An alternative to standardized testing? Dalam J. Wertsch (Ed.), Culture, Communication and Cognition: Vygotskian Perspectives (pp. 273-305). New York: Cambridge University Press.

Dahar, R. W. (1996). Teori-teori belajar (Cetakan ke-2). Jakarta: Erlangga. Eliyanti. (2013). Penerapan model pembelajaran peta konsep pada materi sistem gerak manusia di kelas VIIIC MTs Darul Ihsan Aceh Besar. Tesis tidak dipublikasikan. Banda Aceh: IAIN. 
Ennis, H. R. (1996). Critical thinking. USA: Prentice-Hall Inc.

Gokhale, A. (2002). Collaborative learning enhances critical thinking. Journal of Technology Education, 7(1). Diakses pada tanggal 29 April 2015 dari http://scholar.lib.vt.edu/ejournals/JTE/v7n1/gokhale.jtev7n1.html

Harmin, M., \& Toth, M. (2012). Pembelajaran aktif yang menginspirasi. Jakarta: PT. Indeks.

Hassoubah, I. Z. (2004). Developing creative and critical thinking skill (Cara berpikir kreatif dan kritis). Bandung: Nuansa.

Iskandar. (2009). Psikologi pendidikan: Suatu orientasi baru. Ciputat: Gaung Persada Press.

Kardi. (2003). Penelitian kelas. Surabaya: PPS Universitas Negeri Surabaya.

Khalili, H., Babamohammadi, H., \& Hajiaghajani, S. (2003). The comparison of the effect of two teaching method classic and based on critical thinking strategies on permanent nursing students learning. Semnan Med Sci Univ, 10(5), 53-62.

Mulyasa, E. (2005). Menjadi guru profesional. Bandung: Remaja Rosdakarya.

Novak, J. D., \& Canas, A. J. (2008). The theory underlying concept maps and how to construct and use them. Technical Report IHMC CmapTools, http://cmap.ihmc.us/publications/researchPapers/TheoryUnderlyingConc eptMaps.pdf, diakses pada tanggal 5 Mei 2015.

Pasuloi, S. (2014). Penerapan model pembelajaran generatif untuk meningkatkan keterampilan berpikir kritis dan pemahaman konsep tekanan pada zat cair siswa kelas VIII SMP Negeri 12 Kendari. Tesis tidak dipublikasikan. Kendari: Program Pascasarjana Universitas Halu Oleo.

Pratiwi, R. (2003). Strategi-strategi belajar. Jakarta: Depdiknas.

Provasnik, S., Kastberg, D., Ferraro, D., Lemanski, N., Roey, S., dan Jenkins, F. (2012). Highlights from TIMSS 2011: Mathematics and science achievement of U.S. fourth- and eighth-grade students in an international context (NCES 2013-009). Washington, D.C.: National 
Center for Education Statistics, Institute of Education Sciences, U.S. Department of Education.

Sangadji, E. M. (2010). Metodologi penelitian. Yogyakarta: Andi Offset.

Sidharta, A. (2005). Keterampilan berpikir. Jakarta: Depdiknas.

Sudjana. (2002). Metode statistika. Bandung: Tarsito.

Sutowijoyo. (2002). Penerapan strategi belajar peta konsep yang dilatihkan dengan direct instruction pada pokok bahasan struktur hewan siswa MAN Sidoarjo untuk meningkatkan hasil belajar. Tesis Magister Pendidikan tidak dipublikasikan. Surabaya: PPS Universitas Negeri Surabaya.

Wiersma, 1995. Metode Statistika, Edisi VI. Bandung: Tarsito.

Willingham, T. D. (2007). Critical thinking: Why is it so hard to teach? American Educator, 31, 8-19. 